\title{
Contemporary dārija Writings in Morocco Ideology and Practices
}

\author{
Catherine Miller
}

\section{Introduction}

Starting from the mid 1990s a new political, social and economical context has favored the coming out of a public discourse praising cultural and linguistic plurality as intangible parts of Moroccan identity and Moroccan heritage. The first signs of change occurred at the end of King Hassan II's reign, setting the first steps towards political and economic liberalization. But the arrival of King Mohamed VI in 1999 definitely accelerated the trend toward economic liberalism, development of private media, emergence of a strong civil society, call for democratization and modernization, and the emergence of new urban artistic movements. Within this general context, the linguistic, cultural and artistic issues have been openly and strongly discussed. One of the important points of debate has been the status and functions of what is considered to be the two Moroccan mother tongues: Amazigh (Berber) and dāija (Moroccan Arabic). The main argument raised by a number of "reformists" is that no proper democratization and national building could take place if these mother tongues remain marginalized. They are therefore asking for their promotion, codification and eventually standardization. But whereas Amazigh is considered an endangered language, dārija is not. Therefore their path toward literacy follow different roads and the people calling or acting for their promotion belong to rather different circles. ${ }^{1}$ There is no place here to detail these points, and this paper will focus on dārija writings.

Moroccan Arabic (därija) is the first mother tongue of $72 \%$ of the Moroccan population according to the 2004 National Census and is spoken by $90 \%$ of the population according to the Haut Commisariat au Plan (HCP) 2008. It has been expanding over Amazigh in several areas and is dominant in urban areas (Boukous 2012). It is considered mainly an oral non-standard language although it has some old written literary tradition like poetry and songs (malhūn, zajal see

1 For a few references on the Amazigh issue see for example Boukous 2003 \& 2012, Lakhsassi 2005, Rachik 2006, Pouessel 2010.

(C) CATHERINE MILLER, 2017 | DOI: 10.1163/9789004346178_006 
Elinson this volume). Until recently, written production in dārija was rather scarce and few people had called for the use of written dārija and its promotion as an official national language. However, since the 2000s, things started to change. A number of media figures called for the promotion of dārija. Numerous scholars have pointed to the increasing written use of Moroccan Arabic in various domains such as newspapers, novels, written poetry, internet, sms, social networks, official writings, ads, translations: Aguade (2005; 2006; 2012, 2013), Atifi (2003), Benítez-Fernández (2003, 2010, 2012a\&b); Berjaoui (2002), Caubet (2005, 2007, 2008, 2012, 2013, 2016), Ech-Charfi (2004); Elinson (2013), Ferrando (2012a\&b), Hall (2015) Hickman (2013), Hoogland (2013a \&b); Langone (2003, 2006, 2008), Messaoudi (2002) Miller (2012, 2015), Morgan (2009); Moscoso (2009, 2011), Moustaoui Srhir (2012a), Pérez Cañada et al (2011), Salanitro (2008), Santíllan et al. (2013), Youssi (2013), etc. This quite impressive academic production gives the impression that the last years represent a turning point and that dārija is de facto becoming a written language. Yet, the social, ideological and linguistic impact of these emerging written practices needs more investigations. Many questions remain concerning the profiles of the actors involved in the different types of writings, their objectives, their practices as well as the individual and public reception of these writings according to contexts. Unlike the development of Amazigh within the Royal Institute for Amazigh Culture in Morocco (IRCAM), the written use of dārija is by large an individual, untutored enterprise. What do people write when they claim to write in dārija? What is their stance vis à vis the standard language? Do they really want to establish an autonomous language distinct from fușhā?

These questions are by no means specific to Moroccan Arabic. Writing and codification of oral languages (including pidgin and creole languages, nonstandard dialects or previously unwritten minority languages) are never neutral and straightforward technical acts and are linked to issue of power and subjectivity (Jaffe 2000; Rajah-Carrim 2008, Romaine 2005). For non-standard dialects, one of the key issues is the relationship vis à vis the standard language and the process of autonomization (Kloss 1957). Orthographic and variety choices will either emphasize sameness to or difference from the standard according to ideological and identity aspirations but also pragmatic considerations and contexts. Very often we find a tension between local authenticity and literary prestige. Phonemic orthography and colloquial style/varieties tend to symbolize specificity and authenticity whereas etymological orthography and higher style sound more elegant and literary. In many cases, writers will opt consciously or not for hybrid systems, or what Gunvor Mejdell mentions as strategic bivalence (Mejdell 2014). Processes of literacy and vernacularization of former oral languages appear to follow some general roads from simple 
humourous texts, letters, riddles and folksong to scientific writing in various disciplines, official documents and complete newspapers (Mühleisen 2005). As we shall see, the development of dārija writings follow some of these roads. Like in many other countries we find a gradual move from documenting popular oral culture to more modern form of writing such as newspapers and novels. But the increasing impact of globalization and marketing introduces new written practices.

The paper will first present a brief preliminary historical overview of dārija literacy in Morocco and highlight some key differences and similarities with the Egyptian context. It will then turn to the recent period and question the issue of continuity and changes between past and present written practices. It will describe different profiles of people involved in dārija writings, their objectives, their public stands, their networks and their types of publication. It will analyze how the different actors apprehend the key issue of sameness/difference vis à vis the fuṣha $\bar{a}$ in both discourse and practices. It will point out the inherent ambiguity and disjuncture between ideology and practices.

\section{Writing in dārija: From Oral Heritage to Written Modernity}

As mentioned above the great amount of recent publications on dārija writings leads to the impression that the 2000 gave birth to an unprecedented and massive phenomenon. In fact, dārija writings are not totally new, but generally speaking they were mainly associated with oral literary genres such as zajal and malhün. If we compare the situation of Moroccan dārija with that of Egyptian 'ammiyya two points are noticeable and can explain why this period appeared so radical in Morocco. First, from the late 19th century up to the late 2oth century, Moroccan dārija never reached the cultural prestige of Egyptian āmmiyya and did not have the same historical background as a written language. ${ }^{2}$ This can be related to the fact that during the same period the general cultural and literary production (theater, novels and journals on the written level but also films, series and songs) was less developed in Morocco than in Egypt (Lecerf 1934, Touimi \& al 1974) and that part of the literary production (particularly novels) was/is in French and not in Arabic. The bibliography of Moroccan novels in Arabic established by Al-'Alam and Qâsimî (2003) as well as the panorama of Touimi and al (1974) and Jay (2005) indicate that very few Moroccan novels

2 See Lecerf 1934 for early writings and Doss and Davies 2013 for a fascinating anthology of Egyptian 'āmmiyya writings. 
in Arabic were published up to the early 1980s. From 1952 to 1973, only one or two Moroccan novels in Arabic were published each year (including those published outside Morocco, in Cairo or Beirut). It was only after 1982 that the number of Arabic published novels reached eight or more each year (al-'Alam and Qâsimî 2003). As very well depicted by Jean Lecerf (1934), the 'āmmiyya literary tradition in Egypt and the Levant did not develop against or totally independently from fuṣha literary production but in interaction with it. Therefore it is not surprising that the spreading of dārija writings in the last decade follows a more general development of Moroccan Arabic literature and writings.

Another important historical difference between Morocco and Egypt is that, in the first part of the 2oth century, promotion of dārija had never (or rarely) been advocated by leading Moroccan intellectual figures, unlike what happened in Egypt or Lebanon (Plonka 2004, Zack 2014). So far no Moroccan figures comparable to Salāma Mūsā or Said Al 'Aql have appeared in Morocco, and no writers or journalists like Bayram al-Tunsi, Hussein Shafik or Ya'qūb Șanū' and his journal Abū naḍ̂̄āra zar'a.

In post-independence Morocco (1960-1980s), several important journals (either francophone like Souffle, Lamalif, Intégral or arabophone like Afāq, alAsās, al-thaqāfa al-jadīda) acted as fora for the Moroccan intelligentsia/artists and addressed the issue of what should be the "Moroccan national culture", the role and place of language, education, oral literature, popular culture, arts, etc. (Sefrioui 2013: 169-200). Generally speaking the attitude towards popular culture remains rather ambiguous and contradictory. It never led to the explicit valorization of dārija or Amazigh as potential national literary languages. For most Moroccan intellectuals of the 1960-1970s, the issue of the literary national language was between Arabic (standard Arabic) and French, as many of them were writing in French and considered French to be part of their culture. It seems that it is only in the late 1980 , early 1990 s that the first public stands toward the valorization of dārija started to emerge.

However, like in many other countries, two main domains appeared to have played an important role in the progressive valorization of dārija as a literary language (first oral literary and then written literary language): theater and poetry/oral literature.

Theater ${ }^{3}$ is one domain where the use of Moroccan Arabic ${ }^{4}$ has been commonly practiced, in order to attract the Moroccan public. Dramas with dia-

3 For the history of Moroccan Theater see Baghdad (2009), Messaïa (2012), Ouzri (1997).

4 In early writings, the word dārija never occurred. Moroccan Arabic is called either 'āmmiyya or lahja. 
logues in dārija or a mix of dārija/fușhā had been written as early as the 1930/40s. ${ }^{5}$ darrija was present through popular proverbs, songs and in dialogues representing uneducated persons like in the plays of the Jamā'a huwāh almasrah (The theater lovers Cie) (Baghdad 2009:77). However the use of Moroccan Arabic was not always accepted. Baghdad mentions a polemic between Abdallah Jrari and Abdelkebir Fassi concerning the use of dialect published in the journal Al-Maghreb in 1934 (Baghdad 2009: 4) as well as several articles in the journal As-sa'āda in 1934 (Baghdad 2009: 316). The use of dārija developed in the 1950-196os within the workshops of the Centre Marocain de Recherche Dramatique (CMDD) established by André Voisin. ${ }^{6}$ CMDD trained many major Moroccan playwrights and stage-directors such as Tayeb Saddiki, Abdessamad Kenfaoui, Ahmed Tayeb al-'Alj, Tahar Ouaâziz, Mohammed Saïd Afifi, Farid Ben M'barek, Abdallah Chakroun, and it influenced dozens of other playwrights like Abdeslam Chraïbi or Mohammed Chahraman (Massaiia 2012). All these playwrights participated in the 'marocanization' of theater either through adaptation/translation of international dramas or through modernization of Moroccan traditional forms of performance. ${ }^{7}$ Dārija was often restricted to popular comedies. The most famous cases are the adaptation of Moliere's repertoire by Abdelsamad Kenfaoui and Ahmed Tayeb al-'Alj, the original dramas performed by Firqat Bachir al-Alj (1956-1962), the numerous comedies written by Abdallah Chakroun for the Troupe du Théâtre Arabe de la Radio Marocaine, ${ }^{8}$ as well as the adaptation of Al-harrāz by Abdeslam Chraïbi perfomed by Saddiki's troop Masrah an-nâs. The dialectal styles and registers were inspired by poetic oral traditions like zajal because as stated later by the poet Driss Messnaoui: 9

5 See Baghdad 2009 for an analysis of 30 dramas published between 1925 and 1955 .

6 Established during the Protectorate CMDD gave birth to the Troupe du Théâtre Marocain (Firqat at-tamthil al-maghribi) in 1956 which became then the famous Maâmora Troup (1961974) which produced most of Ahmed Tayeb el-Alj's plays.

7 Among the most famous examples of drama inspired by traditional performances are 3 plays performed by Saddiki's troup: Sulțān Tolba, written by Kenfaoui (1965), Diwān sìdī Abdelrahmān al-Mahjūb written by Saddiki (1967) and Al-Harrāz written by Chraïbi. Inspired by the ḥălqa tradition, they include musical performances by Nass al-Ghiwān and Jill Jilāla. They meet huge popular success. See also Boujloud (1970) by Abdallah Mouâwi or Chahraman's plays within the nādi al-fanni al-marrakshi (Massaïa 2012).

8 Abdallah Chakroun is considered as one of the most prolific and popular Moroccan dramaturge. He is the first one to introduce drama in Moroccan Arabic at the national radio in the early 1950s (Messaïa 2012: 18-25).

9 From Messnaoui's manuscript كاش التعاويد probably written in the 1990s but as far as I know 


$$
\text { اللغه بلا ثوب زجلي تاتبقى لغه عريانه وبالتالي لغه فقيره }
$$

A language without the garment of zajal remains a naked and poor language

Those theatrical texts did not aim at reflecting the daily language (unlike more recent productions) but widened the spectrum of uses of the literary colloquial level. As for "serious" and more intellectual dramas they were mainly written or adapted in fuṣha like the adaptation of Sartre, Camus and Robles by the Firqat al-urūba al-masrahiyya (1945-1995). However there are some exceptions. Saddiki translated/adapted into elevated dārija dramas from Gogol (1957 \& 1970), ${ }^{10}$ Aristophane (1959), Ben Johnson (1960), Ionesco (1963), Beckett (n.d). Other playwrights followed like Yusif Fadul and the al-Barsim troup who made a Moroccan adaptation of Zoo Ztory of Edward Albee (1972). But up to the 200os most of these drama texts were not published and did not circulate as written texts. It is only recently that theatrical anthologies started to be published, such as Kenfaoui's texts ( 5 volumes edited in 2010), al-Alj's texts (3 volumes published by La Fondation des Arts Vivants in 2011) or some of the adaptation by Saddiki of Gogol's and Ben Johnson's plays published by the Ministry of Culture in 2003. As far as I know (but this point needs additional research) none of the leading playwrights of the 1950-1980s made explicit claims in favor of the promotion of Moroccan Arabic, unlike what can be observed today among a number of contemporary dramaturgs like Driss Ksikes (Miller 2009), Jouad Essounani, Ghassan El Hakim or Ahmed Hammoud (Miller \& Abu Al Aazm 2015). According to the stage director Mohammed Zubair, who had been working with Saddiki: "In the 1970s nobody raise the issue of dārija as such. At this time, the need was that the drama could reach the audience. Saddiki worked the language to introduce the Moroccan imaginary and he produced true literary texts, a fuṣha adapted to the Moroccan ears".

Concerning poetry/oral literature, one notices, starting from the 1980 os but more prominently in the 1990s \& 2000s, an increase of written publications on popular oral heritage: specific issues of the journal Afäq on zajal (1992), the monumental anthology of malhün by El-Fassi (1986-1991), publication of ayta songs by El-Bahrawi 2003 \& Nejmi 2007, Nass el-Ghiwane's songs (ES-Sayyid 2007), Jīl Jilāla songs (Riyād \& Sbahani 2010), numerous publications of zajal

not published. Thanks to Ahmed Ech-Charfi who kindly sent me a digitalized copy of this manuscript.

10 See Langone (2006) for a linguistic analysis of the 1970 Saddiqi's adaptation of Gogol's Le journal d'un fou/ en-naqša. 
anthology by Ministry of Culture such as that of Ben'akida in 2007 or Lemsyah 2011, Moroccan proverbs (Lamghari 2009), etc. Several associations (like AMAPATRIL) and academic conferences were dedicated to oral literature, such as the 1998 Marrakech' conference organized and published by the Jam'iyyat huwāh al-malhūn "The association of malhūn lovers" (2002). All these publications and activities represent an important step. Before, publications on oral literature were often written in French/English/Spanish and published abroad. Today these publications are written in Arabic and are published in Morocco either by the Moroccan Royal Academy, the Ministry of Culture or private Moroccan publishing houses. A number of these books are sold at an affordable price on the streets and gain a wider audience. The former oral production can be read and these publications participate in giving a literary status to dārija. However the dārija texts are almost always introduced and commented in fush $\bar{a}$ (the same for the stage directions of the theatrical texts) and therefore keep their orality status.

The interest in Moroccan heritage popular oral literature and the subsequent efforts to collect and write it constitute an ambiguous and complex process. In the 1980s, it developed in a context of political repression and demarcation from the progressive opening of the 1960-1970s. It could then be associated with a politics of conservatism, folklorism, closure on the socalled Moroccan culture and values. But in the same time it elevated the status of the popular culture and participated in the silent valorization of dārija as illustrated by modern forms of zajal poetry by poets like Driss Mesnaoui or Ahmad Lemsyah who defended the literary values of dārija and tried to break the boundary between colloquial zajal and classical shir (Elinson this volume). As pointed out by Ech-Charf, " $\mathrm{t}]$ he promotion of some forms of 'folk' musical art to the status of 'classic' art has also contributed to make Moroccan Arabic a language of 'classic' artistic expression" (Ech-Charfi 2004). Previous cultural domains considered as 'popular, folkloric' became more legitimate and their status improved. The Moroccan situation appears here very similar to many other countries where the first step toward vernacularization of non-standard languages often starts with the writings of oral literature. This step did not disrupt the diglossic hegemonic representation of language hierarchy in Morocco but allowed for the start of subtle shifts within this hierarchy.

This change of perception towards popular culture and popular language indicates that the valorization of dārija has been a gradual process not a sudden change. From the 1980 s to the 2000 s the stance towards the values of därija writings moved from a heritage perspective to a modernist/developmental one. The heritage phase was a kind of low-profile strategy that did not entail public claim towards the promotion of dārija. Today the most striking aspect of the 
public pro-dārija discourse is its visibility and outspoken claims. Embedded in a modernist and democratic discourse, it not only asks for the valorization of dārija literacy as part of the cultural national heritage but for its needed institutional promotion as a national/official standard in order to cope with development.

But the discourses challenging the hegemonic linguistic hierarchy are only one trend among many others who participate in the expanding dārija writing practices without necessarily entailing a radical change in language ideology (Hall 2015).

\section{Writings in dārija in the Years 200os-2010s: Militants, Business and Social Networks}

During the 2000s-2010s, people acting for (or participating in) the writing of dārija formed a rather heteroclite grouping that included media and economic circles such as journalists, advertisers, radio owners, royal advisors but also young artists, writers, psychologists, medical doctors, social activists, translators and a few Moroccan University professors (Caubet 2007 \& 2008, Elinson 2013, Bénitez-Fernández et al 2013, Miller 2015). ${ }^{11}$ These various individual initiatives did not and still do not constitute a homogeneous or a unified movement in terms of ideologies, objectives, justifications and practices. Three main circles or profiles can be identified.

The first circle includes those who adopt explicit public stands toward the necessary promotion and eventually institutionalization of $d \bar{a} r i j a$, advocating a change in the language hierarchy. They form the active minority of "pro-dārija militants", whose exact number and audience is difficult to assess. The 2002 cover and dossier of the francophone weekly TELQUEL, "dārija langue national" $\left(\mathrm{n}^{\circ} 34,15^{-21}\right.$ June 2002) can be considered their first public manifesto. Since the 2000S, TELQUEL has been one of the main voices of the pro-dārija trend and has called for the codification/standardization of written dārija. Yet the militants' attempts to concretize their ideas in practical acts in the writing press and in the educational sector have often raised either skepticism or strong opposition (see below).

The second circle includes actors of the economic circles (including the royal economic consortium). They understand the marketing value of dārija

11 The film Casanayda!, 2007, by D. Caubet, F. Belyazid and A. Mettour (Casablanca: Sigma Production) describes the different figures of the 2006-2007 Darija galaxie. 
as a symbolic vehicle of Moroccan urbanity and modernity but they avoid taking any explicit stands concerning language issues. They actively participated in the public visibility of därija writings (in Arabic or Roman scripts) through the increasing number of advertising boards. Most of the time they mix därija with standard Arabic and/or French to add expressivity, humor and informality. They have play an active role in the shift of iconic association making dārija a symbol of urban consumerism and youth culture (mobile phone). This trend, common to many other countries including other North African countries (Chachou 2012), fits with Monica Heller's analysis that economic arguments are now more authoritative than political ones and govern new forms of communication (Heller 2010).

The third loose circle includes a large majority of lay people, particularly the youth, who have massively adopted därija writings (both in Roman or Arabic scripts) in sms and social networks without necessarily sharing similar opinions concerning what is/or should be the status of dārija. The development of internet, sms and social networks represents the strongest dynamics of spreading dārija writings and the major factor of change in writing practices (for the use of dārija in sms writings and social networks see Berjaoui 2002, Caubet 2003, 2012, 2013, 2016, Hall 2015). Like everywhere in the world, internet opens the door for new writing practices fostering expressivity, informality, humor, refusal of strict social hierarchy and the exhibition of personal subjectivity. The predominance of what has been characterized as the 'expression of the self' (expression de soi) and the 'expressive individuality' in public spaces (Lecomte 2013, Cardon \& Granjon 2010) represents one of the major factors of change of oral and written public discourses.

Therefore, the spread and wider visibility of dārija writings appear to be linked to a large scale of factors and motivations. It would be a mistake to consider that all those who write in dārija are in favor of its institutionalization but at the same time the presence of dārija in so many types of writings and contexts reinforce its association with Moroccanness, from the expressive individuality to the collective construct. No strict boundaries exist between the three circles.

The same fluidity characterizes the impact of political affiliation within pro and anti-dārija movements. The pro-dārija militants tend to present themselves as the emanation of a youth progressive wing and have been often pictured as such particularly during the nayda cultural phenomenon of the mid-2000s (Caubet 2008). However the pro/anti dārija contrast does not reflect a clear left/right or democratic/non-democratic polarization. In both the ruling establishment and the leftist opposition we find quite ambiguous stands. 
King Mohamed VI and his advisors are very keen to present the regime as being in tune with the times vis à vis the traditionalist parties like the nationalist pan-arabist Istiqlal or the Islamist PJD, even when the latter are officially heading the government. The use of darrija in a number of sectors is one of the symbols of this modernity. Adopting the style and the methods of the advertising and marketing circles, the regime does not hesitate to use dārija as part of branding of Morocanness and symbol of patriotism. A symbol of such patriotic marketing strategies is the recycling of the famous red hand with the motto mà tqīsh blādi "don't touch my country". Inspired by the French motto Touche pas à mon pôte during "La marche des Beurs", the dārija motto first appeared in Morocco during the civil demonstrations of 2003 (in support of arrested rockers, then in the aftermath of the Islamist bombing of Casablanca, cf. Caubet 2007) and became the title of a popular song released by the Marrakchi rap group Fnayr in 2004 (Moreno Almeida 2016). Since then it has been used during all kinds of patriotic gatherings and mobilizations: defense of the "Moroccan" Sahara against Polisario, the anti-paedophilia movement, etc. During the demonstrations of February-March 2011, the motto was exhibited all over the main avenues of the capital Rabat on the giant boards owned by Mounir Majidi, a close royal adviser. The regime has tolerated (and even promoted?) the written and oral spread of dârija in the media, the ads and the cultural domains because it serves purposes of expressivity and Moroccan branding. However, King Mohamed vi never inserts dārija in his official Royal discourse whereas Benkiran, the PJD prime minister made himself popular by resorting mainly to dārija during his press conferences. But while the Palace is believed to have backed the idea of introducing dārija as part of a general language reform in teaching, Benkirane and the PJD in fact stood as strong opponents of this idea (see below).

The same ambiguity characterizes the linguistic stands of the leftist wing of the political spectrum: the 2oth February movement. An interesting turn took place in 2011 with the emergence of the movement and subsequent street demonstrations (Moustaoui Shrir 2013, Caubet \& Miller 2016, Caubet 2016 and this volume), that led to new styles of political expressions, rather similar to the Tunisian ones (Lecomte 2013). In February 11th, the movement posted a video where a number of young people and one older lady explained in dārija and Amazigh why they will go down for demonstration on February 2oth. The subtitles of the video were written in Amazigh in tifinagh script, dārija in Arabic script and French - to the exclusion of standard Arabic. ${ }^{12}$ During

12 https://www.youtube.com/watch?v=A_LFoJqnMzw (posted February 2011, 11th, 370.608 
the demonstrations, many written slogans of the movement were in dārija but also in Amazigh, French, English and standard Arabic. In the following weeks and months debates for and against the 2oth February movement, the Constitutional Referendum, the demonstrations, the alliances with the Islamists occupied social networks, blogs, clips, with thousands of written comments in dārija, French, Amazigh, standard Arabic, English and in a mix of several languages on Facebook, Youtube etc. From then on, political discussion in dārija became more and more common and we can say that dārija entered the domain of politics. However, the 2oth February movement never explicitly demanded the officialization of därija (unlike what happened with Amazigh among the Amazigh militants). An important function of dārija in written or oral political discussions on social networks appears to be a discursive one, emphasizing as I mentioned above expressivity and subjectivity.

Before the spring of 2011, there were few political discussions on the Moroccan Facebook. Most members were sharing their personal life-events or their artistic and cultural choices (Caubet \& Miller 2016). Eventually youth expressed their discontent of the main caveats of the Moroccan society (corruption, sexism, unemployment, hypocrisy) as many rap artists were doing, but without direct connection with formal political organizations. dārija was a means to render personal feelings, from joy to anger or frustration without any pretention to adopt an objective and rational discourse encapsulated in a formal language, as many youth consider that political discourses are just bafflegab. From these beginnings, a number of youth became cyber activists and opted for more direct political comments and discussion while keeping the same "free expressiveness" in dārija in their Facebook pages and blogs (Caubet 2016). But not all 2oth February militants write in dārija and a number of activists continue to write in standard Arabic when they want to discuss political issues on a more formal and "objective" register as can be seen on the website of the movement mamfakinch.com: ${ }^{13}$

\section{Q Qui sommes-nous?}

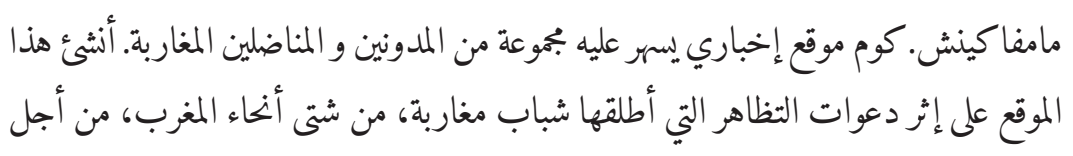

views by 12 December 2014). The video starts with the sentence "ana maghribi, ghadi nekhroj nhar 20 febrayer ..." (I am Moroccan, I will come out on the 2oth of February). https://www.mamfakinch.com, accessed March 2012. 


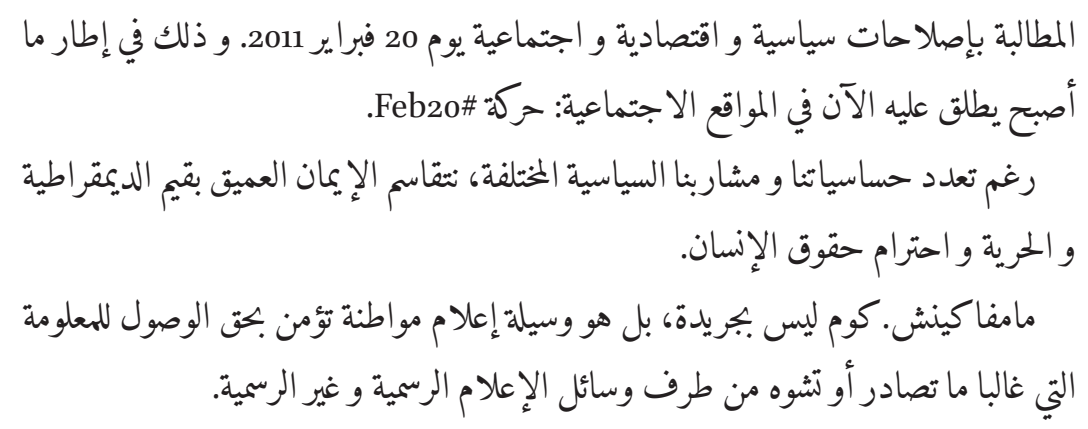

Mamfakinsh.com is a News site animated by a group of Moroccan bloggers and activists. The site was established immediately after February 2oth, 2011 calls for demonstrations launched by young Moroccans, from all across Morocco, demanding political, economic and social reforms. This as part of what became known within social networks as the Feb2o\# Movement. Despite the diversity of our sensitivities and political inclinations, we share a deep faith in the values of democracy, freedom and respect for human rights. Mamfakinsh.com is not a newspaper, it is a citizen media that believes in the right of access to information that are often confiscated or distorted by the official and unofficial media

Facebook posts by 2oth February members reflect a high diversity of levels and styles. It seems here that the personal background of each militant plays an important role as well as his/her vision of political styles. Those who are more educated and had a political background before 2011 are keener to continue to use mainly standard Arabic in their political posts, as someone like Najib Chaouki whose facebook pages contain relatively little dārija. On the other hand, some activists coming from musical/artistic background or from popular background opt for writing mainly in dārija (see Caubet 2016 for the case of Mouad Lhaqed or Mohamed Sokrate). The former select what they consider a neutral, objective style whereas the latter opt for a subjective and more personal style that sounds tougher and closer to "the street" but which is also closer to artistic expression.

Therefore the use of dārija in written political discussions plays an important stylistic function. It does not necessarily indicate a wish to promote dārija as a distinctive and eventually institutionalized language. It rather tends to make political involvement less formal and to mark disconnection from traditional political formations.

In short, if därija writings have expanded tremendously in the last decade, it does not mean that all those who are using it either in personal or public 
writings agree with the idea of its institutionalization. The spread of dārija writings rather coincides, for the time being, with a trend toward coolness and informality. Does it mean that this trend will affect all domains? Analyzing some recent experiences and events, it appears that the 'pro-dārija militants' are faced with the fact that many people still doubt the value of dārija as a 'true literary language' which could become a formal institutional language.

\section{Contesting the Language Hierarchy: Discourses, Actions and Limits}

The discourse of the pro-dārija militants advocating the promotion, valorization, codification and eventually officialization of dārija (also called Moroccan language/lugha maghrebiyya) follows the path of the international movement of defense of minority languages/mother tongues. They refer to the universal trend toward protection and promotion of heritage mother tongues according to language rights enacted by International laws. ${ }^{14}$ They point to the failure of the Morocccan educational system attributed mainly to language problems as recognized in several Moroccan official documents such as the COSEF 1999 or the Plan d'Urgence 2009-2012 with the idea that according to International Institutions such as UNESCO or UNDP promotion of mother tongue (Amazigh and dārija) may enhance educational results and foster Moroccan economic development and cultural creativity. They consider that the Moroccan people need to reconcile with their specific Moroccan identity in order to reinforce democracy and modernity. They believe that promotion of Moroccan mother tongues will help Moroccans emancipate themselves from the former colonial language (French) and from an Arabic classical literary norm that does not correspond to the reality of the Moroccan society.

Their perception of the Moroccan linguistic reality and their ideas about how to ameliorate it are strongly influenced by the model of the historical development of the European national languages. They consider that the diglossic fuṣha /dārija relationship is similar to the Latin/Roman vernaculars of medievals Europe and they conclude that in the Arab world as in Europe, modernity implies the development of the vernaculars as full-fledged languages. We find here the same arguments as those advanced during the 19th century to explain the backwardness of the Arab world. But whereas it was con-

14 Such as Art. 5 of 1960 Unesco Convention against discrimination in Education, 19992000, the UN launching International Mother Language Day, the 2001 UNEsco Charter, etc. 
sidered a kind of colonial ideology during the golden years of pan-arabism, it gains revival during the 1990 at a time of pan-arabism's disillusion. A linking figure between Egypt and Morocco on this issue is the Egyptian psychoanalyst Mustafa Safwan whose publications and stands in favor of Arabic vernaculars have been very well received in the pro-dārija circles in Morocco (Miller 2015). Let me note here that a number of European scholars such as Francisco Moscoso (2011) or Jan Hoogland (2013) strongly support dārija writing and codification and participate in the Moroccan debate.

Pro-dārija militants do not limit themselves to discourses. In order to participate in the making of a literary Moroccan Arabic that could become recognized as a 'full language', a few individuals embark on different writing experiences such as the translation of European classical literary texts (Miller 2015) or the writings of novels (Aguade 2006, 2013; Elinson 2013, Ferrando 2012a\&b, Pérez Cañada \& Salinitro 2011). But these experiences have a limited audience. Another field of experience has been the written press. Three examples are very often quoted:15 Khbār blādnā (خباربلادنا), launched in 2002 by Elena Printice in Tangiers, Al-Amāl (الامال), launched in 2006 by journalist students in Sale and Nichane (نيشان), the Arabic weekly version of TELQUEL created in 2006 by Driss Ksikes (chief editor) and Ahmed Benchemsi (director). Khbār blädnā was a kind of artisanal newspaper, printed at 6 ooo copies, written in dārija in vocalized Arabic script, targeting the poorly literate readers and freely distributed in the medina of Tangiers from 2002 to 2007. Printice's publishing house edited also small books like health booklets, tales, novels, etc, all in the same vocalized Arabic script. Al- Amāl was a short-lived (6 months) experience, printed at 2000 copies and written also in vocalized dārija. Both Khbār blädnā and AlAmāl remain rather marginal experiences. Their philosophy can be related to an old trend of social reformism found for example in Egypt in the late 19th c. that sees dialectal literacy as a means to widen literacy and social consciousness among the poors. It cannot be considered as a decisive participation in the creation of a modern dārija language.

The Nichane experience lasted four years (2006-2010) and had a far wider audience and impact (around 30 ooo issues weekly). Nichane's format was a professional one, written in non vocalized Arabic script like most Arabic newspapers. Nichane attracted considerable international attention and was very often presented as THE Moroccan newspaper in dārija. The renommée

15 For references on these 3 newspaper See Aguade (2012), Benítez-Fernández (2008, 2010, 2012), Caubet (2012), Elinson (2013), Hall (2015), Hickman(2013), Hoogland (2013), Langone (2003), Miller (2012), Moustaoui-Srhir (2012b). 
of Nichane was due to its link to TELQUEL, to its contents, its style, and to the charismatic personality of its director (Ahmed Benchemsi) and first chiefeditor (D. Ksikes). TELQUEL and Nichane always positioned themselves as les portes paroles' of the progressive wing of the civil society. The main goal of Nichane was to spread the progressive stands of TELQUeL in Arabic to the non-francophone readers, with the same freedom of speech. This boldness caused several judicial problems that many attributed to the dārija factor. Nichane had in fact a rather low percentage of dārija more or less estimated at $20 \%$ by J. Hoogland (2013). Dārija was present mainly in the cover titles, the headlines and some specific pages like the interview pages. But why has Nichane so often been considered THE symbol of dārija writings when it contains only a small percentage of dārija? As it has been often observed (Romaine 2005) a few words or sentences suffice to act as tags for the entire text. The subjective perception of Nichane was also certainly influenced by the public stands of TELQUEL in favor of dārija, particularly by the strong position of A. Benchemsi.

Let us note here that there has been quite a divergence of language representation between Driss Ksikes who acted as Nichane chief editor for 3-4 months and Ahmed Benchemsi, TELQUEL director who took over after Ksikes' withdrawal due to Nichane's first trial. In his first editorial “Why Nichane” علاش نيشان Driss Ksikes explains what will be Nichane's style and describes it as "an easy Arabic language, a language of its time and its place, free of rethorical expressions and with a Moroccan fragrance":
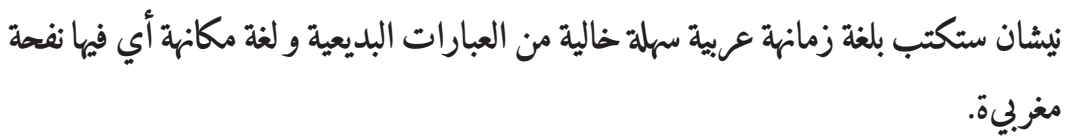

In a personal interview I conducted with him in Rabat in May 2009, he mentioned that "my model was the Egyptian magazine Roz el Youssif and my main idea was to show that Arabic could be an economic and a non redundant language". He added that "we knew that we couldn't create a written dārija from scratch but our goal was to accompany the movement toward the Moroccan language, to reach a clear project of codification, transcription and standardization. As media people we thought that we could maybe force the progress of history". However, he added that "the issue of dārija cannot be set up independently from Arabic. In the written press, the isolation and autonomy of Moroccan dārija from Arabic would not work, because there wouldn't be enough readers. Morocco is far behind Egypt and needs to solve first the issue at the oral level before it works at the written level". This is why he sug- 
gested that dārija should be first used in theater and novels, a task he followed from 2009 to 2012 with the Dabateatr (Miller 2009, Miller and Abu El Aazm 2014).

As for Ahmed Benchemsi, he always emphasized the structural gap between dārija and fusha and called for the rapid institutionalization of dārija in several editorials in TELQUEL:

Our sole common language is dārija. Some translate dārija by Moroccan Arabic. I don't agree. It's Moroccan only. Yes, Moroccan includes a majority of words of Arab origin, but a small majority. There are as many words from Berber, French and Spanish origin.

TELQUEL 230, June 2006

Only dārija integrates all the obscured faces of our identity. It's it (dārija) which should be standardized, used as teaching medium in our schools, and sooner or later constitutionalized.

TELQUEL, May 9 th 2009

Despite their different language stands, both Ksikes and Benchemsi never wrote their editorial in "plain dārija" and like most other Nichane journalists they opted for a mix variety, but each one with his own style. There are a few dārija sentences in Ksikes' editorials (بصراجة). These sentences render oral discourse and are always introduced by commas, a practice found in other Moroccan newspapers like al-Masa' or Ahdath maghrebiyya (Miller 2012):

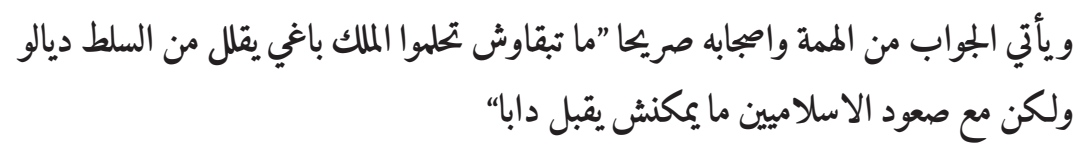

And the answer from El Hima and his friends comes quickly 'Don't stay dreaming, the King wants to resign from his power, but with the raising of the Islamists he cannot do it now'.

$16-22 / 9 / 2006$

Somewhat more mixing is found in Benchemsi's editorials (entitled ديريكت) and translated from French by Benchemsi himself. He often peppered his text with dārija words and expressions without demarcating them by comas. Below are two sentences of the same editorial published in its French version in TELQUeL and in its Arabic version in Nichane the 23/1/2010. 
On avait fini par les oublier. La publication des recommandations de l' Instance équité et réconciliation avait pourtant été un moment fort de la 'nouvelle ère'

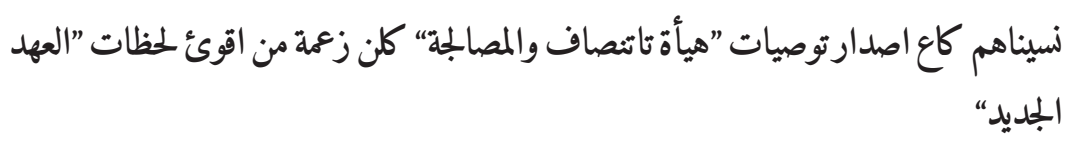

Où en sommes-nous de la constitutionnalisation des droits de l'homme? On n' a encore rien vu venir. En tout cas rien de ce qui était essentiel pour rompre définitivement avec les pratiques du passé

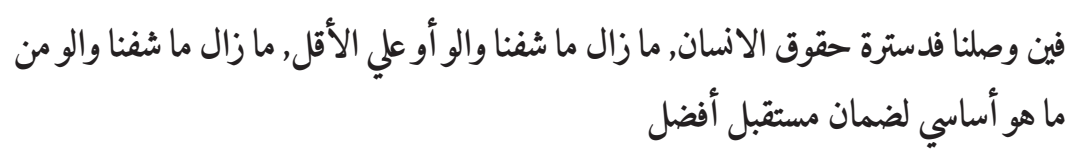

Ahmed Benchemsi is certainly one of the very few Moroccan journalists who tried as much as he could to introduce dārija in his political editorials. His writings certainly deserve deeper linguistic analysis. However, Benchemsi never succeeded to make Nichane a dārija newspaper. Most of the other Nichane journalists wrote dominantly in standard Arabic and the ambitious project of codification/standardization never really concretized.

All the experiences quoted above that try to push dārija in the domain of the written press came to an end around 2009-2010. Since then, no printed or online newspaper adopted dārija as 'une carte de visite', even good.ma, the online version of Nichane (except for some personal blogs). What remains in most newspapers is the rather traditional discursive use of some dārija words and expressions for stylistic purposes (popular wisdom, irony, indignation etc.).

A number of conclusions can be drawn from the Nichane experience. First, it does not matter how people really write as there is no direct association between the real language level of the text and people's perception. If the text is claimed to be in dārija, if it contains a few dārija tags (wallu, za'ma, 'alaš), then it is perceived to be in dārija whatever its level. Second, the marginal presence of dārija within journalistic writings indicates that this domain is still perceived as a "serious" literary domain not suitable for "plain" dārija, particularly if the journalist wishes to sound serious and objective. The militant discourse wants to disrupt the language ideology but still it cannot win over it in practices in all domains. dārija is not yet perceived as a legitimate serious literary language. Third, the exact identity of what could or should be the long awaited codified da arija remains unclear for the time being, even if some common rules start 
to emerge. One is the dominant trend towards the use of Arabic script with an etymological orthography, albeit with many variants. This orthography can be found in most Moroccan newspapers, novels, students' production (Gago 2016) and is more and more present on social networks (Caubet 2016). But yet no codified literary dārija has been fixed and nationally accepted, because as mentioned before, writings of dārija remained largely an individual enterprise. It is certainly this absence of a recognized literary dārija norm that makes its entry in formal domains such as education unconceivable for a large part of the population, at least currently.

The fierce polemic arose in 2013-2015 following the suggestion to introduce dārija as a medium of education in the first years of schoolings, which highlights the limits of the dârija legitimation. The debate was launched by publicist \& makhzen insider Nourredine Ayouch, through his Zakoura Foundation. The Foundation is involved in literacy courses within rural areas. Relying on this experience, N. Ayouch actively militates for educational reforms and for the use of dārija as a medium of instruction in initial and primary schools. ${ }^{16}$ The Foundation organized two International Conferences in Casablanca in 2010 and 2013. The first one (La Langue, Les Langues, Casablanca June 2010) focused on the language situation in Morocco compared to a number of countries which have gone through language reforms, like Turkey and Greece. The second Conference (Colloque International sur l'éducation, Le Chemin de la Réussite, 4-5 October 2013) discussed the needs of a large educational reform. It took place only two months after the 2oth August 2013 Royal Speech, where Mohamed VI asked for an urgent educational reform and harshly criticized the PJD-led government for its failure concerning educational reforms. The conference was considered to be more or less backed by the Palace and was attended by representatives of the World Bank and Microsoft, high official figures such as Ministers of Education and two Royal Advisors, Fouad El Himma and Omar Azziman. Both the 2010 and 2013 conferences concluded with several recommendations concerning the place and role of language in Education. They called for the need to introduce the mother tongues (Amazigh and dārija) as a medium of instruction in early years of schooling to enhance literacy. The idea was not totally new. It was already suggested in the 1999 Chartre Nationale de l'Education et de la Formation (COSEF 1999) (cf. de Ruiter (2001)

16 Hall 2015 provides a very interesting account of a similar experience of adult literacy programs in rural areas held by a USAID sponsored association Passerelle and shows that in reality the teachers were quite reluctant to dārija writings and use mainly dārija as oral medium. 
and Benítez (2010)). But Cosef's recommendations had never been implemented. In both Conferences, the recommendations of the Zakoura Foundation were always careful to highlight the convergence between classical and Moroccan Arabic. But this carefulness did not stop the fury of the opponents.

The 2013 Conference raised an unprecedented mediatic storm, from October 2013 to February 2014 (Caubet \& Miller 2016, Miller 2016, Hall 2015, Schulthies 2014). Many people, including intellectual and political figures stand against this idea. On November 27th, a debate on the Moroccan TV Channel $2 \mathrm{M}$ between Nourredine Ayouch and the famous historian Abdallah Laroui was watched by 5 million people. During this media storm nobody seriously discussed which kind of dārija could or should be used as a medium of instruction in the first years of schooling. None of the efforts of the Zakoura Foundation to present literary Moroccan Arabic as a legitimate bridge that will help to create a convergent Arabic that combines dārija and fuṣha were heard, believed or considered irrelevant. For most of his detractors, Ayouch (as Benchemsi before him) is acting for the domination of French over Arabic; dārija is a Trojan horse that will reinforce the prestige of the foreign languages.

In 2015, the polemic continued within the Conseil Supérieur de l'Education (CES). CES' main function was to write a strategic report to be presented to the King that will define the new educational policy. According to numerous press releases, CES members (nominated by the King and including N. Ayouch) did not agree on the place of dārija in schools. This lack of agreement is said to have caused serious delay in the writing of the final strategic report. Last press releases in September 2015 indicated that opponents to teaching in dārija finally succeeded to kick out the suggestion from the strategic report. ${ }^{17}$

\section{Conclusion}

Dārija is definitely making its ways in various spaces of expression, communication and artistic creation. Its diversity in terms of dialectal varieties, registers and styles makes it a powerful tool of expression at both the oral and written level. The success of a number of Moroccan Facebook or Youtube links attract-

17 A first draft was presented in February 23th 2015 to the King but not made public. See http://www.aufait.ma/2015/02/25/langue-arabe-un-collectif-veut-la-tete-de-belmokhar _638522 and http://www.panorapost.com/la-darija-nouvelle-ligne-de-front-de-la-bataille -de-leducation-nationale. 
ing million viewers by circulating cartoon using youth dārija slang attests the powerful attraction of dārija (see for example the case of Bouzebbal in Ziamari \& Barontini 2016). ${ }^{18}$

Mixed with fushāa, dārija contributes to the expressivity of Arabic in more formal levels and creates a feeling of proximity with the Moroccan public. It is more and more closely associated with Moroccan patriotism in songs, political motto and political discourses, and on web sites.

But, at least for the time being, its standardization and institutionalization as a Moroccan official language is not perceived as a social and political priority by what seems to be a large portion of the population. The reasons for such reluctance are many. It can be attributed to the weight of the traditional language hierarchy supported by the traditionalist and pan-arabist political intelligentsia who cannot imagine the rupture with fuṣhā. It can be also understood for very pragmatic reasons. The failure of the Arabic public educational system to provide economic opportunities for the young Moroccan graduates is deeply internalized by most Moroccan Youth people and their parents (Boutieri 2016). They are deeply convinced that opportunities are provided by the mastery of international languages such as French and English. They fear that the teaching of Moroccan Arabic will not ameliorate their situation but rather worsening it. Finally the idea that the gap between fușhā and dārija is so wide that it became almost two different languages does not seem to be shared by the majority of the people who attended Moroccan Arabic schools, due to the fact that Moroccan Arabic is de facto very present at the oral level in schools (Boutieri 2016).

\section{References}

EDNA = Estudios de Dialectología Norteafricana y Andalusi.

Aguade, Jordi. 2005. “Darle Al Pico: Un ‘Bestiaro’ de Youssouf Amine El Alamy en Arabe Marroqui". EDNA 9: 245-265.

Aguade, Jordi. 2006. "Writing dialect in Morocco". EDNA 10: 253-274.

Aguadé, Jordi. 2012. "Monarquia, dialecto e insolencia en Marruecos: el caso Nichane".

Pp. 441-464 in De los manuscritos medievales a internet: la presencia del arabe vernaculo en las fuentes escritas, edited by Mohamed Meouak, Pablo Sanchez \& Angeles Vicente. Zaragoza: Universidad de Zaragoza.

18 https://www.youtube.com/watch?v=RB7jSX-620o\&ebc=ANyPxKqW4x58OJhXw -YXRslrw_7qTFULYqENAw7b6O_wılwVWSgVwmEFJ55Y4YDvePsc6IjAhjheplc6 _fVIzV ${ }_{52} \mathrm{UxK}_{1} \mathrm{E} 2 \mathrm{IZrQ}$. 
Aguade, Jordi 2013. "Des romans diglossiques: le cas de Youssef Fadel". Pp. 207-220 in Evolution des pratiques et représentations langagières dans le Maroc du Xxième siècle, edited by Montserrat Benítez Fernández, Catherine Miller, Jan Jaap De Ruiter, \& Youssif Tamer. Paris: l' Harmattan.

Al-'Alam, Abderraḥim \& Qāsimī, Moḥammed. 2003. Moroccan Novels written in Arabic 1942-2003 (in Arabic). Rabat: Ministère de la Culture.

Atifi, Hassan. 2003. "La variation culturelle dans les communications en ligne: analyse ethnographique des forums de discussions marocains". Langage et Société 104: 5782.

Fondation Zakoura Education. 2010. Actes du Colloque International La langue, les Langues. Casablanca: Fondation Zakoura Education.

Baghdad, Mustafa. 2009. Al-masrahiyyāt al-maghrebiyya al-'awla (1924-1956). Casablanca: Dār al-thaqāfa.

Bencakīda, Nahād. 2007. Majmae al-kalām. Antūlūjìyā al-zajal al-maghrebì. Rabat: Top Press.

Benítez Fernández, Montserrat. 2003. "Transcripción al árabe marroquí de mensajes de teléfono móvil”. EDNA 7:153-163.

Benítez Fernández, Montserrat. 2008. "Arabe marroqui como proyecto editorial: es una experience posible?" Pp. 37-54 in Acta des III Congresso Internacional de Arabe Marroqui: estudio, enseñanzay aprendizaje 8-9 de mayo de 20o8, edited by Leyla AbuShams. Bilbao: Universidad del Pais Vasco.

Benítez Fernández, Montserrat. 2010. La politica lingüistica contemporanea de Marrueccos: de la arabizacion a la aceptacion del multilingüismo. Zaragoza: Instituto de estudios Islamicos y del Oriente Proximo.

Benítez-Fernández, Montserrat. 2012. "Al-?Amāl. Otro intento fallido de escribir en dārija marroqui". Pp. 379-392 in Dynamiques langagières en Arabophonie, edited by A. Barontini, C. Pereira, A. Vicente \& K. Ziamari. Zaragoza: Universidad de Saragoza.

Berjaoui, Naser. 2002. "Aspects of the Moroccan Arabic Orthography with Preliminary Insights from the Moroccan Computer-Mediated Communication". Pp. 431-468 in Chat-Kommunikation: Sprache, Interaktion, Sozialität \& Identität in synchroner computervermittelter Kommunikation, edited by M. Beißwenger. Stuttgart: Bidem-Verlag.

Boukous, Ahmed. (ed.). 2003. L'Amazigh: les défis d'une renaissance. Rabat: Revues Prologues 27/28.

Boukous, Ahmed. 2012. Revitalisation de la langue Amazigh. Rabat: I RCAM.

Boutieri, Charis 2016. Learning in Morocco. Language Politics and the Abandonned Educational Dream. Bloomington \& Indianapolis: Indiana University Press.

Cardon, Dominique and Granjon François. 2010. Médiactivistes. Paris: Presses de Sciences-Po.

Caubet, Dominique. 2004. "L'intrusion des téléphones portables et des SMs dans 
l' arabe marocain en 2002-2003". Pp. 247-270 in Parlers Jeunes ici et là-bas, pratiques et représentations, edited by Dominique Caubet et als. Paris: l' Harmattan.

Caubet, Dominique. 2007. "Génération darija!" in EDNA 9: 233-243.

Caubet, Dominique. 2008. "From Movida to Nayda in Morocco: the use of dārija (Moroccan Arabic) in the artistic creation at the beginning of the 3 rd Millenium". Pp. 113-124 in Between the Atlantic and the Ocean 7 th International Conference of AIDA, edited by Stefan Prochazka \& V. Ritt-Benmimoun. Wien: LIT Verlag.

Caubet, Dominique. 2012. "Apparition massive de la dārija à l'écrit à partir de 20082009: sur le papier et sur la toile: quelle graphie? Quelles régularités?". Pp. 377-402 in De los manuscritos medievales a internet: la presencia del arabe vernaculo en las fuentes escritas, edited by Mohamed Meouak, Pablo Sanchez \& Angela Vicente. Zaragoza: Universidad de Zaragoza.

Caubet, Dominique 2013. "Maroc 2011 - Messagerie instantanée sur l'internet marocain: Facebook, dārija et parlers jeunes". Pp. 207-220 in Evolution des pratiques et représentations langagières dans le Maroc du Xxième siècle edited by Montserrat Benítez Fernández, Catherine Miller, Jan Jaap de Ruiter, \& Yousef Tamer. Paris: l' Harmattan.

Caubet, Dominique 2016. "New elaborate written forms in Darija: blogging, posting and slamming in 2015 Morocco". In Routledge Handbook on Arabic Linguistics, edited by Abbas Benmamoun and Reem Bassiouney. London-New York: Routledge.

Caubet, Dominique \& Catherine Miller 2016. "Quels enjeux sociopolitiques autour de la darija au Maroc?", in Langues et Mutations sociopolitiques au Maghreb, edited by Foued Laroussi and Chérif Sini. Rennes: Presses Université de Rennes.

Chachou, Ibtissem 2012. "L'algérianité exprimé au travers de la publicité ou la variation sociolinguistique au service du marketing”. Pp. 46-54 in Langues et médias en Méditerranée, edited by Abdenbi Lachkar. Paris: l' Harmattan.

Chekroun, Abdellah. 2009. Sanawāt fî kitābat al-masrahiyyāt w-al-tamthüliyyāt. Casablanca: Imprimerie Najāḥ al-jadīda.

De Ruiter, Jan Jaap. 2001. “Analyse sociolinguistique de la Chartre Nationale". Pp. 29-48, in Plurilinguisme au Maroc et dans les communautés marocaines en Europe, edited by Jan Jaap de Ruiter. Fès: (Langues et Linguistiques 8).

Doss, Madiha \& Davies, Humphrey 2013. Writings in Egyptian 'ämmiyya (in Arabic). Cairo: The General Egyptian Book Organization.

Ech-Charfi, Ahmed 2004. "Standardisation of Moroccan Arabic: A Sociolinguistic Study". PhD thesis. Rabat: University Mohamed v.

El-Bahrawī, Hassan. 2003. Fann al-Eayta fil-maghreb (The Art of Ayta in Morocco). Rabat: Union des Ecrivains Marocains.

El Fassi, Mohamed. 1986-1991. Maealmat al-malhün (Encyclopedia of malhoun). Rabat: Publications de l'Académie du Royaume du Maroc. (xı volumes)

Elinson, Alexander. 2013. "dārija and changing writing practices in Morocco". International Journal of Middle Eastern Studies 45 (04): 715-730. 
Es-Sayyid, Omar. 2007. Kalām al-Ghiwān. Casablanca: Maṭbaca al-Najāḥ al-jadīda.

Ferrando, Ignacio. 2012a. "Apuntes sobre el uso del dialecto en la narrativa marroqui moderna". Pp. 349-358, in De los manuscritos medievales a internet: la presencia del arabe vernaculo en las fuentes escritas edited by Mohamed Meouak, Pablo Sanchez \& Angeles Vicente. Zaragoza: Universidad de Zaragoza.

Ferrando, Ignacio 2012b. "El árabe marroquí en la novela del siglo XXI. El caso de Salem Himmich y su obra فنتة الرؤوس و النسوة" Pp. 415-426 in Dynamiques langagières en Arabophonie. edited by A. Barontini, C. Pereira, A. Vicente \& K. Ziamari. Zaragoza: Universidad de Zaragoza.

Gago Gómez, Laura. 2015. "Aproximación a la situación sociolingüística de TángerArcila. Análisi variacional a partir de un corpus de léxico disponbiel árabe marroqui". Doctoral Thesis, Universidad de Salamanca.

Hall, Jennifer L. 2015. "Debating Darija: Language Ideology and the Written Representation of Moroccan Arabic in Moroco". PhD thesis: University of Michigan.

Heller, Monica 2010. "The commodification of language". Annual Review of Anthropology 39: 101-114.

Hickman, Kathryn G. 2013. "Training linguistic sensibilities. Memory, Memorization and the writing of Moroccan Arabic". Master thesis Chicago: University of Chicago. Hoogland, Jan. 2013a. "Towards a Standardized Orthography of Moroccan Arabic Based on Best Practices and Common Ground among a Selection of Authors," Pp. in Árabe marroquí de la oralidad a la enseñaza. Actes du sème Congreso International de Árabe Marroqui, Madrid 2012., edited by Paula Santillan-Grimm et als Madrid: Ediciones de la Universidad de Castilla La Manca.

Hoogland, Jan. 2013b. "L' arabe marocain, langue écrite." Pp. 175-188 in Evolution des pratiques et représentations langagières dans le Maroc du XxIème siècle, edited by Montserrat Benitez Fernandez, Catherine Miller, Jan Jaap De Ruiter, and Youssef Tamer. Paris: l' Harmattan.

Jaffe, Alexandra 2000. "Introduction: Non-standard orthography and non-standard speech". Journal of Sociolinguistics 4: 497-513.

Jameiyya Huwāh al-Malhūn. 2002. The poetry of Malhūn between popular and learned cultures (in Arabic). Marrakech: Jameiyya Huwāh al-Malhūn.

Jay, Selim. 2005. Dictionnaire des écrivains marocains. Casablanca: Eddif.

Kenfaoui, Abdelssamad. 2010. Théâtre, collection en six volumes (Bouktef, Soltan Tolba, A Moula Nouba, Soltan Balima, Si Taki et Barbe Bleue, Aphorismes). Casablanca: Editions Maghrébines.

Kloss, Heinz. 1967. “'Abstand languages' and 'Ausbau languages'”. Anthropological Linguistics 9:29-41.

Lakhsassi, Abderrahmane. 2005. "Amazighité et questions identitaires". Cahiers de recherche du Centre Jacques Berque 3: 187-201.

Lamghāri, Hishām. 2009. Zayn al-kalām. Casablanca: Dār al-Afāq al Maghrabiyya. 
Langone, Angela D. 2003. "Khbār blādna. Une expérience journalistique en dialectal marocain". EDNA 7:143-151.

Langone, Angela D. 2006. "Jeux linguistiques et nouveaux style dans la masrahiyya «ənnəqša », le déclic, écrite en dialectal marocain par Ṭ-Ṭiyyəb əṣ-Ṣaddīqi.” Pp. 243-261 In L'arabe dialectal, enquêtes, descriptions, interprétations, Actes de Aida 6, edited by Salah Mejri. Tunis: Cahiers du C.E.R.E.s. 13.

Langone, Angela D. 2008. "Facteur D (dārija) et nouvelle génération marocaine: la musique entre innovation et tradition". Pp. 273-285, in Between the Atlantic and the Ocean, Proceedings of the 7 th International Conference of AIDA, edited by Stephan Prochazka \& Veronika Ritt-Benmimoun. Vienna: LIT Verlag.

Jean Lecerf. 1932-1934. Littérature dialectale et Renaissance arabe moderne. Paris. Bulletin de l'Institut Français de Damas.

Lecomte, Romain 2013. "De l'expression de soi à l' engagement citoyen: une analyse de la politisation de la prise de parole d' internautes tunisiens". Pp. 51-84 in Les réseaux sociaux sur internet à l'heure des transitions démocratiques, edited by S. Najar. ParisTunis: IRMC-Karthala.

Lemsyeh, Ahmed 2011. al-asmāl al-zajaliyya (2 volumes). Rabat: Ministère de la Culture. Massaia, Ahmed. 2012. Répertoire du Théâtre marocain. Rabat: Ministère de la Culture. Mejdell, Gunvor 2014. "Strategic bivalency in written 'mixed style': A reading of of Ibrāhīm 'Īsā in al-Dustūr”. Pp. 273-278 in alf lahža wa lahža Proceedings of the gth AIDA Conference, edited by Olivier Durand, Angela Langone and Giuliano Mion. Wien: Lit Verlag.

Messaoudi, Leyla. 2002. "Les technolectes et les ressources linguistiques. L' exemple du code de la route au Maroc". Langage et Société 99: 53-75.

Miller, Catherine. 2009. "Passage du français au darija dans la pièce de théâtre Il/huwa par le DabaTeatr", Communication au Colloque International Artistic Creation in Arabic Dialects from Egypt to Mauritinia, Université de Cadiz, 19-20 Novembre 2009 http://halshs.archives-ouvertes.fr/docs/oo/59/24/53/PDF/millerdabateatrweb.pdf.

Miller, Catherine. 2012. "Observations concernant la présence de l'arabe marocain dans la presse marocaine arabophone des années 2009-2010". Pp. 419-440 in De los manuscritos medievales a internet: la presencia del arabe vernaculo en las fuentes escritas; edited by Mohamed Meouak, Pablo Sanchez \& Angela Vicente. Zaragoza: Universidad de Zaragoza.

Miller, Catherine. 2015. "Des passeurs individuels au mouvement linguistique: itinéraires de quelques traducteurs au Maroc." Pp. 203-232 in Le social par le langage, La parole au quotidien, edited by Myriam Achour. Tunis-Paris: IRMC/Karthala.

Miller, Catherine. 2016. "Evolution des pratiques, évolutions des représentations? Petit retour sur le débat autour de la valorisation de la darija au Maroc". Revue Etudes Berbères 10: 101-120.

Miller, Catherine and Selwa Abou El AAzm 2014. "Le Dabateatr citoyen 2009-2013: un 
nouveau théâtre dans la ville?". Pp. 27-49 in Présence de nouvelles scènes culturelles en Méditerranée: du Global au Local, edited by Hadj Miliani et Ibtissem Chachou. Mostaganem: Université Abdel Hamid Ibn Badis \& CRAsC.

Moscoso Garciá, Francesco. 2009. "Comunidad lingüistica marroqui en los foros y chats. Expresion escrita, norma o anarquia?”. Al-Andalus-Maghreb 16: 209-226.

Moscoso Garciá, Francesco 2011. "El arabe marroqui: una lengua y no un dialecto. Educar en la lengua maternal". Revista de Estudios Internacionales Mediterraneos 10: 133-144.

Moustaoui Srhir, Adil 2012a. "Language Planning, Standardization and Dynamics of Change in Moroccan Arabic". Dialectologia 9:53-69.

Moustaoui Srhir, Adil 2012b. "New Dynamics of Change and New Language Resource: A Case Study of the Standardization of Moroccan Arabic". Pp. 157-170. In Exploring linguistic standards in non-dominant varieties of pluricentric languages, edited by C. Amoros Negre, R. Muhr, C. Fernández Juncal, K. Zimmermann, E. Prieto \& N. Hernández. Wien: Peter Lang Verlag.

Moustaoui Srhir, Adil 2013. "Resistiendo el régimen sociolingüístico institucional: Nuevas prácticas lingüísticas como estrategias de comunicación en el seno del Movimiento 20 de Febrero en Marruecos". Madrid:Asociación de Estudios Sobre Discurso y Sociedad.

Mühleisen, Suzanne. 2005. "Introduction: Creole Languages in Creole Literatures, Status and Standardization." Journal of Pidgin and Creole Languages 20(1):1-14.

Nejmi, Hassan 2007. Ghinä’ al-EAyta. Casablanca: Toukbal.

Nicosia, Aldo 2016. "Le Petit Prince in Moroccan Arabic: A lexical perspective". Pp. 421431 in Arabic Varieties Far and Wide. Proceedings of the nth International Conference of Aida-Bucharest 2015, edited by George Grigore and Gabriel Biţună. Bucharest: editura universitãtii din bucaresti.

Ouzri, Abdelwahed 1997. Le théâtre au Maroc, structures et tendances. Casablanca: Toukbal.

Pérez Cañada, Luiz M.; Salinitro, A. 2011. "La edición en árabe marroquí: creación y traducción”, Pp. 288-319 in IV Congreso Árabe Marroqui: más allá de la oralidad Toledo, 23 y 24 abril de 2010, edited by B. Herrero Muñoz-Cobo, L. M. Pérez Cañada, M. Aragón Huertas \& F. Moscoso Garciá. Almeria: Universidad de Almeria.

Pouessel, Stéfanie 2010. Les identités Amazighs au Maroc. Paris: Non Lieu.

Plonka, Arkadiusz 2004. L'idée de la langue libanaise d'après Sa îd 'Aql. Paris: Gueuthner. Rajah-Carrim, Aaliya 2008. "Choosing a spelling system for Mauritian Creole". Journal of Pidgin and Creole Languages 23: 1996-227.

Rachik, H. (ed.) 2006. Usage de l'identité Amazigh au Maroc. Casablanca.

Riyad, L. \& Sbahāni, M. T. 2010. Lammā ghānī al-maghreb Mūlay Tahir Sbahāni w Jūl Jìlala. Tanger: Slìkī akhwān.

Romaine, Suzanne 2005. "Orthographic practices in the standardization of pidgins and 
creoles: Pidgin in Hawai'i as anti-language and anti-standard". Journal of Pidgin and Creole Languages 20: 101-140.

Salanitro, A. 2008. "La dāriža marocchina tra status ufficiale e realtà sociolinguistica: considerazioni sul ruolo del colloquiale nella società del Marocco". PhD thesis, Università Ca'Foscari di Venezia.

Santillán Grimm, Paula, Perez Cañada, Luiz. \& Moscoso Garciá, Francesco. (eds.) 2013. Árabe marroquí de la oralidad a la enseñaza. Actes du 5 ème Congreso International de Árabe Marroquí, Madrid 2012. Madrid: Ediciones de la Universidad de Castilla La Manca (UCLM).

Schulthies, Becky 2014. "The Language of Instruction or the Instruction of Language? Reviewing official debates in Morocco". Anthropological News 55 .

Sefrioui, Kenza. 2013. La revue Souffle 1966-1973. Espoir de révolution culturelle au Maroc. Casablanca: Editions du Sirocco.

Touimi, Mohammed, Omar Benjelloun, Abdelkebir Khatibi, \& Mohammed, Kably 1974. Ecrivains marocains du Protectorat à 1965. Choix et Traduction de l'arabe. Paris: Sindbad.

Zack, Liesbeth 2014. "The use of the Egyptian dialect in the satirical newspaper Abu naḍ̣āra zar’a". Pp. 465-478 in Alf lahğa wa lahğa: Proceedings of the gth Aida Conference edited by Olivier Durand, Angela Langone \& Giuliano Mion. Wien, Berlin: LIT Verlag.

Ziamari, Karima \& Alexandrine Barontini. 2016. "Les liaisons dangereuses: médias sociaux et parlers jeunes au Maroc. Le cas de Bouzebbal”. Pp. 279-288 in Arabic Varieties Far and Wide. Proceedings of the nth International Conference of Ä̈da, edited by George Grigore and Gabriel Bituna. Bucharest: Editura Universitatii din Bucuresti. 